\title{
Effect of protein deprivation on insulin-like growth factor- binding proteins in rats
}

\author{
BY TSUTOMU UMEZAWA, YUKIKO OHSAWA, YUTAKA MIURA, \\ HISANORI KATO AND TADASHI NOGUCHI \\ Department of Agricultural Chemistry, Faculty of Agriculture, The University of Tokyo, Bunkyo-ku, \\ Tokyo 113, Japan
}

(Received 12 June 1990-Accepted 12 October 1990)

\begin{abstract}
The effect of protein deprivation on plasma concentration of insulin-like growth factor-binding proteins (IGFBP) was studied in rats. A significant decrease in the concentration of IGFBP of molecular weight (mass) approximately $40 \mathrm{kDa}$ was observed in protein-deprived rats. There was no prominent effect of protein deprivation on the concentration of IGFBP with molecular weights of about $30 \mathrm{kDa}$ or 22-24 kDa. The binding capacity to plasma IGFBP of exogenously-added ${ }^{125}$ I-labelled insulin-like growth factor-1 ${ }^{125}$ I-IGF-1) was also studied. IGFBP of molecular weight about 30 and $22-24 \mathrm{kDa}$ (the native form of this protein is presumed to be $29 \mathrm{kDa}$ ) in protein-deprived rat plasma bound more ${ }^{125} \mathrm{I}$ IGF-1 than those in protein-fed rat plasma. This suggested that these IGFBP in protein-deprived rat plasma are relatively unsaturated by endogenous IGF-1. The response of IGFBP to protein deprivation which was elucidated in the present investigations add further evidence to our previous assumption that IGFBP play an important role in protein nutrition.
\end{abstract}

Insulin-like growth factor-1: IGF-binding protein: Protein deprivation: Rat

Insulin-like growth factor-1 (IGF-1) is a protein, the concentration of which is largely affected by growth hormone and nutritional status of man and animals (for review, see Van Wyk, 1984; Froesch et al. 1985; LeRoith \& Raizada, 1989). In a previous paper, we demonstrated that the plasma concentration of $\mathrm{IGF}-1$ is regulated by the quantity and nutritional quality of dietary proteins (Takahashi et al. 1990).

This hormone has been shown to circulate in blood in forms conjugated with several kinds of proteins known as IGF-binding proteins (IGFBP) (Cohen \& Nissley, 1975; Hintz $\&$ Liu, 1977). At least three groups or species of IGFBP have been demonstrated in human or rat plasma (Kaufmann et al. 1977, 1978; Binoux et al. 1982) (Fig. 4 explains the species of IGFBP). The first involves a complex of the molecular weight (mass) $150 \mathrm{kDa}$. This IGFBP can be chemically dissociated into two components which have been named as acidlabile subunit (ALS) and acid-stable subunit (ASS) (Furlanetto, 1980; Martin \& Baxter, 1985; Wilkins \& D'Ercole, 1985; Baxter, 1988). IGF is bound to ASS. ASS is a glycoprotein of molecular weight approximately $53 \mathrm{kDa}$ (Martin \& Baxter, 1986). However, sodium dodecylsulphate-polyacrylamide gel electrophoresis (SDS-PAGE) gives a smaller molecular weight component, i.e. about $40 \mathrm{kDa}$ (Rechler et al. 1989a). This subunit has been recently named IGFBP-3 (Ballard et al. 1989). The second IGFBP has a molecular weight of approximately $30 \mathrm{kDa}$. This protein has been purified from amniotic fluid (Drop et al. 1984; Povoa et al. 1984; Busby et al. 1988 a) and the recent nomenclature is IGFBP-1 (Ballard et al. 1989). The third is that with a molecular weight approximately 22-24 kDa (Hardouin et al. 1987). However, this protein may exist as a glycoprotein of molecular weight a little smaller (approximately $29 \mathrm{kDa}$ ) than IGFBP-1, and may be 
converted to the 22-24 kDa molecule by the action of $\mathrm{N}$-glycanase (Rechler et al. $1989 a, b$; Yang et al. 1989). These authors suggested that this $29 \mathrm{kDa}$ protein is a $\mathrm{N}$-terminal $29 \mathrm{kDa}$ fragment of IGFBP-3.

In human plasma, IGF-1 is primarily found to be conjugated with IGFBP-3 and shows an apparent molecular weight of $150 \mathrm{kDa}$ (Moses et al. 1979; Hardouin et al. 1987). The plasma concentration of this IGFBP has been shown to be affected largely by growth hormone (Moses et al. 1976; White et al. 1981; Grant et al. 1986). The physiological significance of other IGFBP is controversial (Knauer \& Smith, 1980; Cornell et al. 1987; Elgin et al. 1987; DeMellow \& Baxter, 1988; Ritvos et al. 1988; Busby et al. 1989).

In the previous paper (Takahashi et al. 1990), we demonstrated that IGF-1 is found in rat plasma in two forms, i.e. one associated with a protein of molecular weight $150 \mathrm{kDa}$, and another with that of $40 \mathrm{kDa}$ or smaller. The total and relative amounts of IGF-1 bound to each protein were affected by dietary protein source. Furthermore, there was a large difference between the dietary groups in the capacity of plasma fractions to bind exogenously-added ${ }^{125}$ I-labelled IGF-1 ( ${ }^{125}$ I-IGF-1). The explanation of these was based on the extent of saturation of IGFBP with endogenous IGF-1.

In the previous experiments, we employed a method of gel filtration for separation of IGFBP. That method could not differentiate all the molecular species of IGFBP. A recently-introduced method which separates IGFBP on sodium dodecylsulphate-polyacrylamide gel electrophoresis (SDS-PAGE) makes it possible to differentiate the small differences among IGFBP (Hossenlopp et al. 1986; Hardouin et al. 1987). In the present investigations, SDS-PAGE was used and the previous studies on the effect of protein status on plasma IGFBP in rats extended.

MATERIALS AND METHODS

Animals and diets

Male Wistar rats were obtained from Japan SLC company (Shizuoka, Japan) and used throughout the experiments. The body-weight was approximately $100 \mathrm{~g}$. The protein-free and casein $(120 \mathrm{~g} / \mathrm{kg}$ diet) diets were prepared as described previously (Takahashi et al. 1990). Rats were fed on these diets and water ad lib. for 1 week. At 11.30 hours on the 8th day they were anaesthetised with Nembutal, and blood samples were taken from the carotid artery.

\section{Materials}

IGF-1 was purchased from Boehringer Mannheim-Yamanouchi (Japan), and bovine serum albumin (BSA) from Sigma. Nylon membrane (GeneScreen Hybridization Transfer Membrane) was from NEN Research Products, Boston, MA, USA. Na ${ }^{125}$ I $\left(3.7 \times 10^{9} \mathrm{~Bq} / \mathrm{ml}\right)$ was obtained from Amersham (Japan Radioisotope Association). A molecular marker kit for SDS-PAGE was obtained from BioRad. Other chemicals were of the purest grade available commercially.

\section{Determination of immunoreactive IGF-1 concentration and that after extraction with acid-ethanol (or total immunoreactive IGF-1 concentration)}

The methods were the same as described previously (Takahashi et al. 1990).

$$
\text { Iodination of IGF-1 with }{ }^{125} I
$$

The method was similar to that reported previously (Takahashi et al. 1990). Briefly, $10 \mu 1$ $\mathrm{Na}^{125} \mathrm{I}(37 \mathrm{MBq}$ ) and $10 \mu \mathrm{l}$ chloramine $\mathrm{T}$ solution ( $1 \mathrm{mg}$ dissolved in $1 \mathrm{ml} 0 \cdot 2 \mathrm{M}$-phosphate buffer, $\mathrm{pH} 7 \cdot 4$ ) were added to $10 \mu \mathrm{I} \mathrm{IGF-1} \mathrm{solution} \mathrm{(recombinant} \mathrm{human} \mathrm{IGF-1,} 1 \mu \mathrm{g} / 10 \mu \mathrm{l}$ 
water). The mixture was mixed well and kept at room temperature for $60 \mathrm{~s}$. Then sodium metabisulphite solution ( $2.5 \mathrm{mg}$ sodium metabisulphite dissolved in $1 \mathrm{ml} 0.05 \mathrm{M}$-phosphate buffer, $\mathrm{pH} 7.5$ ) was added in order to stop the reaction. From this mixture, the labelled IGF-1 was extracted three times with 100,50 and $50 \mu \mathrm{l}$ of transfer solution (1 litre of the solution contained $10 \mathrm{~g}$ potassium iodide, $80 \mathrm{~g}$ sucrose and $1 \mathrm{~g}$ Triton $\mathrm{X}-100$ in distilled water). The extract was subjected to gel-filtration on a plastic column packed with Sephadex G-25M (bed volume $9 \mathrm{ml}, 50 \mathrm{~mm}$ height; Pharmacia) previously equilibrated with phosphate-buffered saline solution $(0.14 \mathrm{M}$-sodium chloride- $0.01 \mathrm{M}$-sodium phosphate, $\mathrm{pH} 7.5$ ) containing $10 \mathrm{~g}$ BSA/l. The labelled IGF-1 was eluted with the same phosphatebuffered saline solution. Two peaks with radioactivity were eluted. The first peak was labelled IGF-1. The preparation was stored at $-20^{\circ}$. Just before use, this stored preparation was purified further by gel-filtration using an acryl column $(15 \mathrm{~mm}$ diameter and $500 \mathrm{~mm}$ height) packed with Sephacryl S-200. The labelled IGF-1 was eluted with a solution containing $0.15 \mathrm{M}$-sodium chloride, $0.01 \mathrm{M}$-Tris-hydrochloric acid, $10 \mathrm{~g} \mathrm{BSA} / 1$ and $0.5 \mathrm{~g}$ sodium azide/ 1 . Three radioactive peaks were obtained; i.e. the peak associated with BSA, free IGF-1 and inorganic ${ }^{125} \mathrm{I}^{-}$. The second peak was used as the ${ }^{125} \mathrm{I}-\mathrm{IGF}-1$ preparation.

\section{Analysis of IGFBP by Western ligand blotting}

The method of Hossenlopp et al. (1986) and Hardouin et al. (1987) was employed. Briefly, $40 \mu \mathrm{l}$ plasma was mixed with an equal volume of SDS solution (1 litre of the solution contained $100 \mathrm{~g} \beta$-mercaptoethanol, $200 \mathrm{~g}$ glycerol, $50 \mathrm{~g}$ SDS, $20 \mathrm{mmol}$ Tris and $2 \mathrm{mmol}$ EDTA, pH 6.8) and incubated for $15 \mathrm{~min}$ at $60^{\circ}$. A portion $(40 \mu \mathrm{l})$ of the mixture was used for SDS-PAGE. The gel was $135 \times 135 \mathrm{~mm}$ and $2 \mathrm{~mm}$ thick with $125 \mathrm{~g}$ polyacrylamide $/ 1$. The polyacrylamide gel was prepared according to Laemmli (1970). The electrophoresis was performed at $180 \mathrm{~V}$. After electrophoresis, proteins were transblotted to nylon membrane. After blotting, the membrane was incubated for $30 \mathrm{~min}$ at $4^{\circ}$ in $30 \mathrm{~g} \mathrm{NP40/1}$ saline solution $(0 \cdot 15 \mathrm{M}-\mathrm{NaCl}, 0.01 \mathrm{M}-\mathrm{Tris}-\mathrm{HCl}, 0.5 \mathrm{~g}$ sodium azide/l). Then the membrane was again incubated in $10 \mathrm{~g} \mathrm{BSA} / 1$ in the saline solution for $6 \mathrm{~h}$ at $4^{\circ}$. By these incubation procedures, non-specific binding of labelled IGF-1 was minimised. The membrane was incubated further in $1 \mathrm{~g}$ Tween $20 / 1$ saline for $10 \mathrm{~min}$ at $4^{\circ}$ in order to remove BSA. The membrane was then incubated with $1.8 \mathrm{ml}{ }^{125} \mathrm{I}-\mathrm{IGF}-1$ solution $\left(2-3 \times 10^{6}\right.$ counts $/ \mathrm{min}$ $(\mathrm{cpm}))$ for $10 \mathrm{~h}$ at $4^{\circ}$ and then washed twice with the Tween 20 solution (each washing was for $15 \mathrm{~min}$ at $4^{\circ}$ ). The radioactivity which was bound to IGFBP was detected by autoradiography. After autoradiography, the portion with radioactivity on the filter was cut out and the radioactivity was determined with a gamma-counter (Aloka Auto Well Gamma System ARC-500).

\section{Cross linking of ${ }^{125} I-I G F-1$ with IGFBP}

In order to determine the amount of IGFBP not associated with endogenous IGF-1, the following procedure (Hardouin et al. 1987) was used.

Purified ${ }^{125} \mathrm{I}-\mathrm{IGF}-1(10 \mu \mathrm{l}$, approximately $50000 \mathrm{cpm}$, the amount was not exactly estimated but was more than that to saturate the vacant IGFBP) was mixed with $20 \mu$ l plasma and the mixture was incubated for $16 \mathrm{~h}$ at $4^{\circ}$. Then $10 \mu \mathrm{l}$ disuccimydyl suberate (DSS) solution (10 mg DSS $/ \mathrm{ml}$ dimethylsulphoxide-water mixture $(80: 20, \mathrm{v} / \mathrm{v})$ ) was added and the mixture was incubated for $15 \mathrm{~min}$ at $4^{\circ}$. By this incubation, ${ }^{125}$ I-IGF-1 was covalently bound to IGFBP which had not been saturated with endogenous IGF-1. To this mixture, $40 \mu \mathrm{l}$ SDS solution was added and incubated for $15 \mathrm{~min}$ at $60^{\circ}$. A $40 \mu 1$ portion of the solution was used for SDS-PAGE. Electrophoresis conditions were as described 
previously except the gel was $1 \mathrm{~mm}$ thick. After electrophoresis, the gel was dried by a geldryer and the radioactivity in the dried gel was detected by autoradiography. The results of autoradiography were analysed using a densitometer (Computing densitometer ACD18; ATTO, Tokyo, Japan). This method may make it possible to determine the amount of IGFBP not saturated with endogenous (unlabelled) IGF-1. However, other possibilities cannot be excluded (see p. 113).

\section{Statistical analysis}

The results were analysed statistically by one way classifications (analysis of variance, Snedecor \& Cochran, 1967).

\section{RESULTS}

Table 1 shows the body weight changes and plasma immunoreactive IGF-1 or total IGF1 concentration in the rats fed on the casein or protein-free diet. The results confirm our previous observations (Takahashi et al. 1990).

Fig. 1 shows the results of autoradiography after Western ligand blotting. Four radioactive bands were observed, i.e. two bands at about $40 \mathrm{kDa}$, one at about $30 \mathrm{kDa}$ and one at about $22 \mathrm{kDa}$. The two bands found in the area of $40 \mathrm{kDa}$ were found in the $A$ fraction of the earlier gel filtration (Fig. 2). These two bands probably are the same protein but glycosylated to different extents (Rechler et al. 1989 a, b; Yang et al. 1989). The bands at about $30 \mathrm{kDa}$ and about $22 \mathrm{kDa}$ were in the $\mathrm{C}$ fraction obtained earlier. In Fig. 2, $30 \mathrm{kDa}$ IGFBP showed two bands (the larger one will be referred to as $30 \mathrm{kDa}$ IGFBP and smaller one as $29 \mathrm{kDa}$ IGFBP). The amount of $22 \mathrm{kDa}$ band was very small. Therefore, we concluded that the two bands at about $40 \mathrm{kDa}$ (Fig. 1) were derived from the large binding protein (Takahashi et al. 1990) and bands at about 30 and $22 \mathrm{kDa}$ were derived from the small binding protein. Tentatively, we refer to the two bands at $40 \mathrm{kDa}$ as IGFBP-3, and the band at $30 \mathrm{kDa}$ as IGFBP-1. From the assumption described on $\mathrm{p}$. 113,29 $\mathrm{kDa}$ IGFBP is tentatively presumed to be undegraded or native $29 \mathrm{kDa}$ IGFBP and $22 \mathrm{kDa}$ IGFBP as degraded $29 \mathrm{kDa}$ IGFBP. Rechler et al. $(1989 a, b)$ and Yang et al. (1989) suggested that this protein is the N-terminal fragment of IGFBP-3.

Table 2 shows the results of the determination of radioactivity found in the fractions of Fig. 1. These results were obtained by counting the radioactivity after dissecting the bands. The total radioactivity of the bands at about $40 \mathrm{kDa}$ decreased significantly after protein deprivation.

Fig. 3 shows the results of cross-linking experiments. Three bands, one at $150 \mathrm{kDa}$ and two bands at about 35 and $33 \mathrm{kDa}$, were found in protein-deprived rats and two additional bands, one at about $25 \mathrm{kDa}$ and another at about $20 \mathrm{kDa}$ in casein-fed animals. The dense bands at the bottom of the figure show the unbound ${ }^{125} \mathrm{I}-\mathrm{IGF}-1$ which is comparable to peak D reported in the previous paper (Takahashi et al. 1990, Fig. 2). This confirms that an excess amount of labelled IGF-1 for saturation of vacant IGFBP was used in the experiments. The molecular weight of IGF-1 cross-linked to IGFBP must be apparently larger than the binding protein not associated with IGF-1 by the molecular weight of IGF-1, $7 \mathrm{kDa}$. Besides, the acid-labile subunit, the molecular weight of which has been reported to be about $90-110 \mathrm{kDa}$ (Baxter et al. 1989), and acid-stable subunit, i.e. $40 \mathrm{kDa}$ binding protein (Furlanetto, 1980; Martin \& Baxter, 1985, 1986; Baxter, 1988), are assumed to be non-covalently bound to each other in native condition. This complex is dissociated into subunits during SDS-PAGE. However, if plasma is treated with DSS, covalent bonds between ASS, ALS and IGF-1 are presumed to be formed and this complex 
Table 1. Effect of protein deprivation on plasma immunoreactive (IR) insulin-like growth factor- 1 (IGF-I) concentration in rats

(Values are means for five rats)

\begin{tabular}{lccccc}
\hline \hline & $\begin{array}{c}\text { Initial body-wt } \\
\text { Diet }\end{array}$ & $\begin{array}{c}\text { Final body-wt } \\
(\mathrm{g})\end{array}$ & $\begin{array}{c}\text { IR-IGF-1 (A) } \\
(\mathrm{U} / \mathrm{ml})\end{array}$ & $\begin{array}{c}\text { Total IGF-1 (B) } \\
(\mathrm{U} / \mathrm{ml})\end{array}$ & $\mathrm{A}: \mathrm{B}$ \\
\hline Protein-free & 106 & 97 & $1 \cdot 12$ & $6 \cdot 78$ & $0 \cdot 16$ \\
Casein $(120 \mathrm{~g} / \mathrm{kg}$ diet) & 107 & 147 & 6.49 & $25 \cdot 1$ & 0.26 \\
Residual mean square & $7 \cdot 2$ & $20 \cdot 6$ & $0 \cdot 10$ & 30.8 & 0.003 \\
$F$ & 0.35 & 306 & 716 & 27.4 & $9 \cdot 75$ \\
$P$ & $>0.05$ & $<0.01$ & $<0.01$ & $<0.01$ & $<0.05$ \\
\hline \hline
\end{tabular}

For details of dietary regimen, see p. 106.

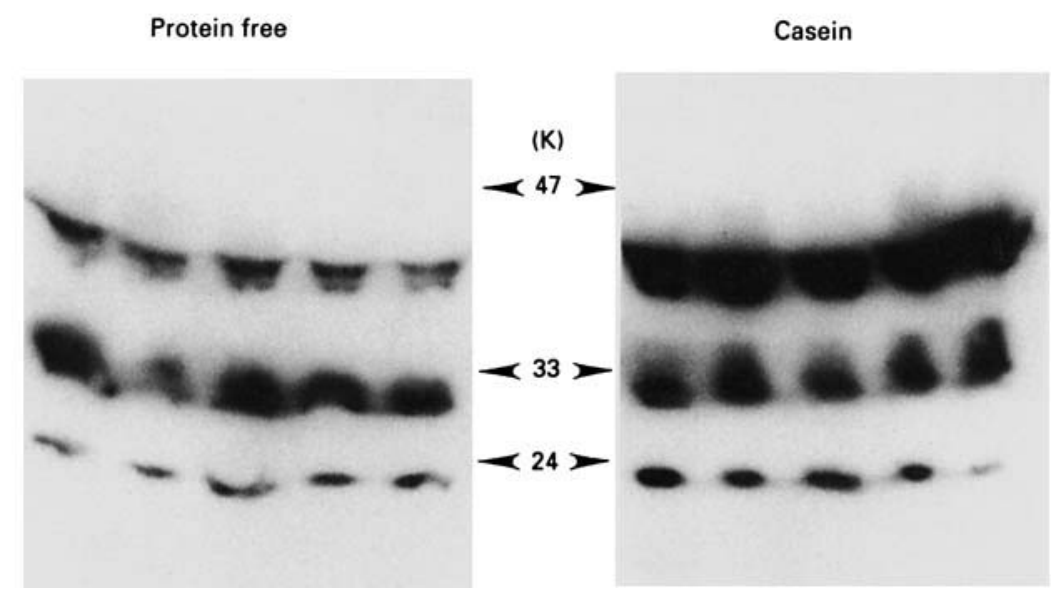

Fig. 1. Sodium dodecylsulphate-polyacrylamide gel electrophoresis (SDS-PAGE) of plasma insulin-like growth factor (IGF)-binding proteins detected by Western ligand blotting (Hossenlopp et al. 1986; Hardouin et al. 1987). Rat plasma was subjected to SDS-PAGE. After electrophoresis, proteins were transferred to nylon membrane. The proteins which bound ${ }^{125}$ I-labelled-IGF-1 were detected by autoradiography. Rats were fed on protein-free or casein $(120 \mathrm{~g} / \mathrm{kg}$ diet) diets (for details of dietary regimen, see p. 106).

is probably found at $150 \mathrm{kDa}$. The band at about $35 \mathrm{kDa}$ is presumed to be $30 \mathrm{kDa}$ IGFBP (IGFBP-1) (Fig. 1) with bound radioactive IGF-1. The difference from the expected molecular weight (if $30 \mathrm{kDa}$ IGFBP binds IGF-1, the molecular weight must be $37 \mathrm{kDa}$ ) is probably due to the three-dimensional conformation of the complex (Baxter et al. 1987; Rosenfeld et al. 1989). The band at about $33 \mathrm{kDa}$ may be $22 \mathrm{kDa}$ IGFBP in Fig. 1 . However, $22 \mathrm{kDa}$ IGFBP is presumably produced during incubation with SDS (for discussion, see p. 113) and the native form of the proteins may be $29 \mathrm{kDa}$ IGFBP in Fig. 2. If plasma is treated with DSS before treatment with SDS, conversion of $29 \mathrm{kDa}$ IGFBP to $22 \mathrm{kDa}$ is presumed to be inhibited. Therefore, undegraded $29 \mathrm{kDa}$ IGFBP is found at the position of $33 \mathrm{kDa}$. We assume that the small difference in expected $v$. observed molecular weight (a $29 \mathrm{kDa}$ IGFBP plus IGF-1 should give $36 \mathrm{kDa}$ complex) in this case is also due to the conformation of the complex. The proteins which appear as the bands at about 25 and $20 \mathrm{kDa}$ after conjugation with ${ }^{125} \mathrm{I}$-IGF-1 were not detected by Western ligand blotting. These proteins may be sensitive to SDS-PAGE and lose the ability to bind 

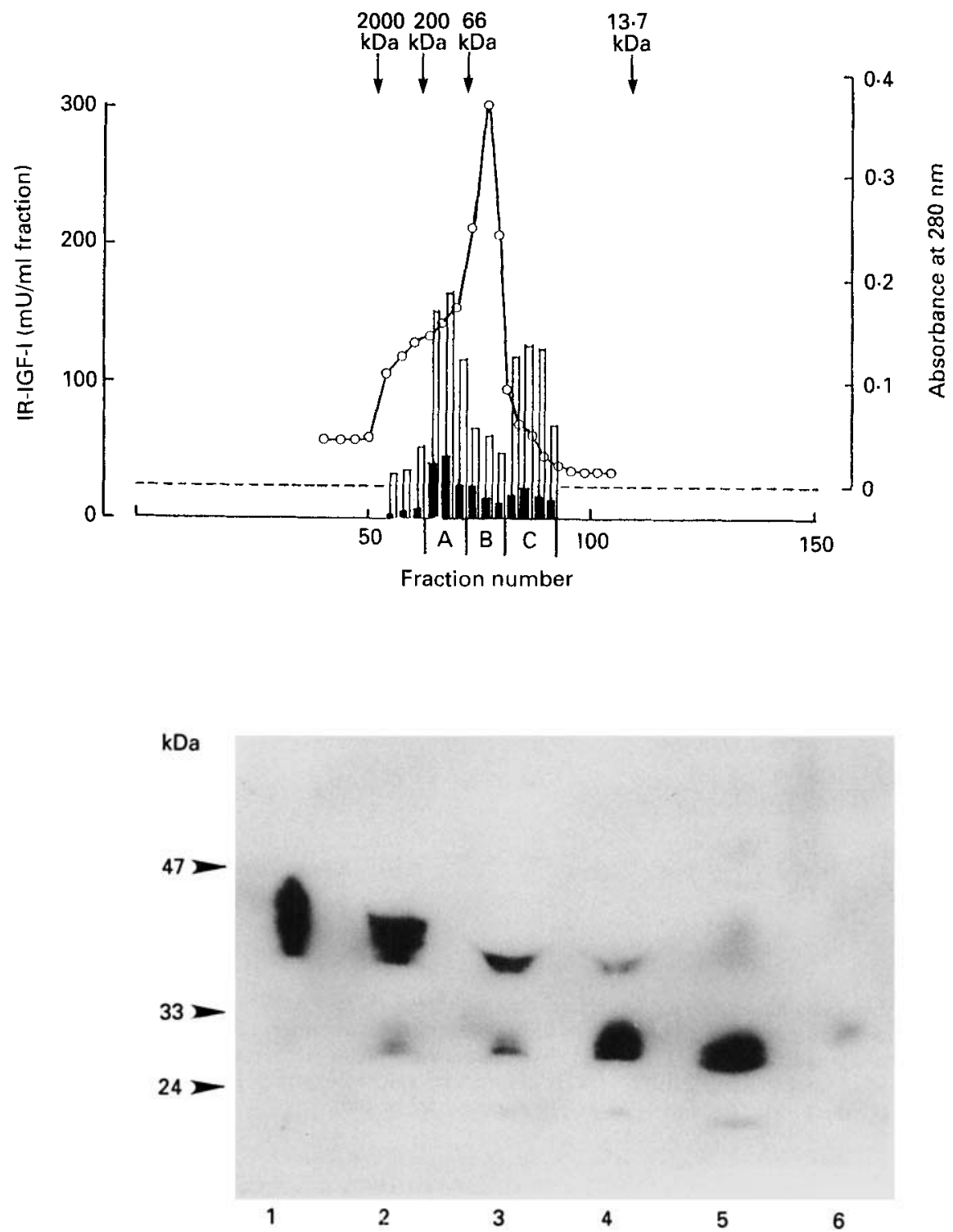

Fig. 2. Sodium dodecylsulphate-polyacrylamide gel electrophoresis (SDS-PAGE) of the fractions of Sephacryl S200 gel filtration of rat plasma proteins and detection of insulin-like growth factor-binding proteins by Western ligand blotting (Hossenlopp et al. 1986; Hardouin et al. 1987). Rat plasma was subjected to Sephacryl S-200 gel filtration. The pooled fractions were used as the samples for SDS-PAGE. After SDS-PAGE, insulin-like growth factor-binding proteins were detected by Western ligand blotting (see Fig. 1). (1), Fractions 56-61; (2), fractions $62-67$; (3), fractions $68-73 ;(4)$, fractions $74-79 ;(5)$, fractions 80-85; (6), fractions $86-91$. For gel filtration, see Takahashi et al. (1990). IR-IGF-1, immunoreactive IGF-1.

IGF-1 after SDS-PAGE. The origin of these proteins will also be discussed later. Figure 4 explains the relationship of the bands among Figs, 1, 2 and 3.

Table 3 shows the results of densitometry of Fig. 3. The results are expressed as the relative density of the bands and are not absolute values. The bands of about 35 and 33 $\mathrm{kDa}$ (IGFBP-1 and $29 \mathrm{kDa}$ IGFBP conjugated with ${ }^{125} \mathrm{I}-\mathrm{IGF}-1$ ) increased significantly in protein-deprived rats. This is presumed to be the increase in unsaturated IGFBP, because 
Table 2. The effect of protein deprivation on the plasma insulin-like growth factor (IGF)binding proteins which were detected by the activity to bind ${ }^{125} I$-labelled IGF-1 after SDSpolyacrylamide gel electrophoresis (counts $/ \min \times 10^{-2}$ )

(Values are means for five rats)

\begin{tabular}{lcccc}
\hline Protein species ... & $40 \mathrm{kDa}$ & $30 \mathrm{kDa}$ & $22 \mathrm{kDa}$ & Total \\
Diet & & & & \\
\hline Protein-free & 37 & 60 & 11 & 108 \\
Casein (120 g/kg diet) & 130 & 55 & 15 & 200 \\
Residual mean square & 222 & 71 & 19 & 391 \\
$F$ & 96.5 & 1.09 & 1.75 & $52 \cdot 7$ \\
$P$ & $<0.01$ & $>0.05$ & $>0.05$ & $<0.01$ \\
\hline
\end{tabular}

For details of dietary regimen, see p. 106.

Protein free

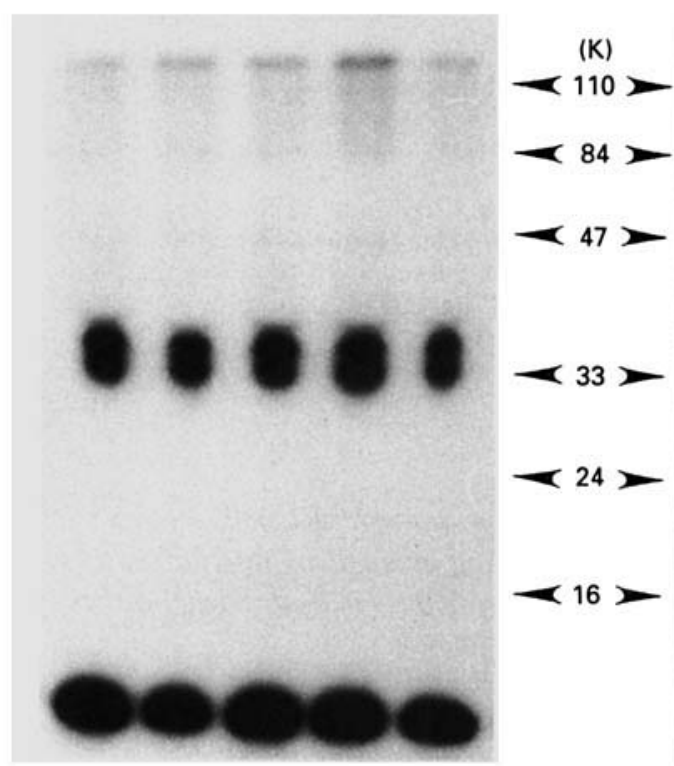

Casein

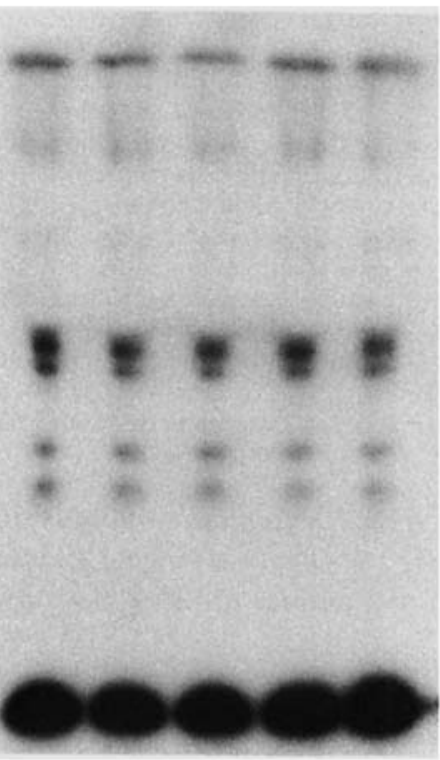

Fig. 3. Sodium dodecylsulphate-polyacrylamide gel electrophoresis (SDS-PAGE) of the insulin-like growth factor-binding proteins covalently bound with labelled IGF-1. ${ }^{125}$ I-labelled IGF-1 was covalently bound to IGFbinding proteins in rat plasma which had the capacity to bind exogenously added IGF-1. Then the plasma proteins were subjected to SDS-PAGE. The labelled proteins were detected by autoradiography. Rats were fed on proteinfree or casein diets (for details of dietary regimen, see p. 106).

the total amount of these IGFBP did not change significantly (Table 2). These observations are consistent with the former observation that the small BP in protein-deprived rats binds a larger amount of labelled IGF-1 than that in protein-fed rats (Takahashi et al. 1990). On the contrary, the bands at $150 \mathrm{kDa}, 25 \mathrm{kDa}$ or $20 \mathrm{kDa}$ increased in casein-fed rats (Fig. 3). The increase in radioactivity at $150 \mathrm{kDa}$ is probably due to the increase in unsaturated $150 \mathrm{kDa}$ IGFBP, because the total amount of its subunit, i.e., $40 \mathrm{kDa}$ IGFBP in Fig. 1, increased significantly. The reason for the increase in the 25 and $20 \mathrm{kDa}$ bands, i.e. whether this is due to the increase in either unsaturated BP or in the total amount of the BP, cannot 


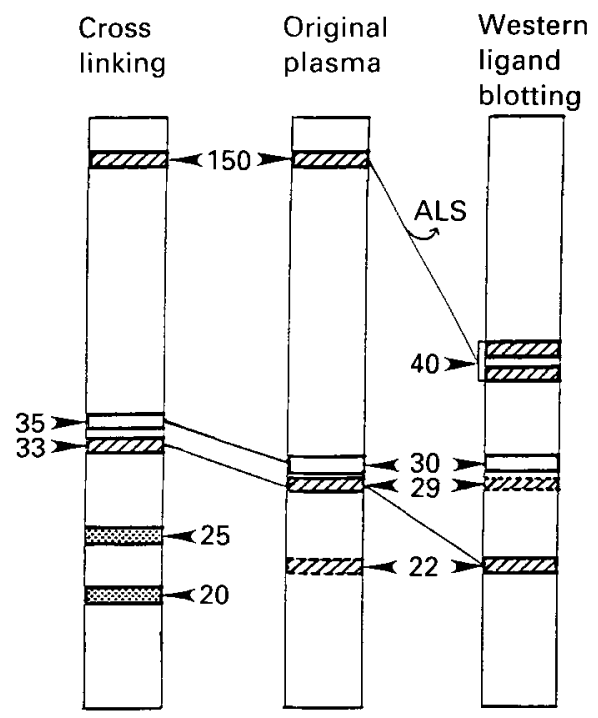

Fig. 4. Schematic representation of the relationship among the bands of IGF-binding proteins (IGFBP) shown in Figs. 1-3. Cross linking: IGFBP detected by autoradiography after sodium dodecylsulphate-polyacrylamide gel electrophoresis (SDS-PAGE) of the plasma mixed with ${ }^{125}$ [-IGF-1. After mixing with ${ }^{125}$ I-IGF-1, the plasma IGFBP were covalently linked with the labelled IGF-1 by means of disuccimidyl suberate. Therefore, the molecular weights of IGFBP are apparently larger than that of the original IGFBP by the molecular weight of IGF-1 (approximately 7,000). For details of the method, see Materials and Methods (pp. 107-108). Original plasma: supposed IGFBP in rat plasma deduced from evidence presented by the present authors and many others. Besides the molecular species presented in this figure, at least two species, which form 25 and $20 \mathrm{kDa}$ bands after cross-linking, must be present in the plasma. Western ligand blotting: IGFBP detected by blotting with the ligand $\left({ }^{125} \mathrm{I}-\mathrm{IGF}-1\right)$ after SDS-PAGE of the plasma. For details of the procedure, see Materials and Methods (p. 107). ALS : acid-labile subunit of $150 \mathrm{kDa}$ binding protein. Bands existing in small amounts, if any (zZZz); IGFBP-3 (ZZ); IGFBP-I (二); unidentified IGFBP (W). Numbers are molecular weights (kDa). The band at $29 \mathrm{kDa}$ is the N-terminal $29 \mathrm{kDa}$ protein of $40 \mathrm{kDa}$ IGFBP-3 (Rechler et al. $1989 a, b$ ).

Table 3. The densitometric analysis of the autoradiogram of ${ }^{125}$ I-labelled insulin-like growth factor $(I G F)-1$ which was bound to plasma IGF-binding proteins of rats fed on a protein-free or casein diet (values are expressed as the relative optical density by densitometry)

(Values are means for five rats)

\begin{tabular}{lccccc}
\hline $\begin{array}{l}\text { Protein species... } \\
\text { Diet }\end{array}$ & $150 \mathrm{kDa}$ & $\begin{array}{r}35 \mathrm{and} \\
33 \mathrm{kDa}\end{array}$ & $25 \mathrm{kDa} 20 \mathrm{kDa}$ & Total \\
\hline $\begin{array}{l}\text { Protein-free } \\
\text { Casein }(120 \mathrm{~g} / \mathrm{kg} \text { diet) }\end{array}$ & 142 & 1865 & $\mathrm{ND}$ & $\mathrm{ND}$ & 2007 \\
$\begin{array}{l}\text { Residual mean square or } \\
\text { mean square (for 25 and 20 kDa) }\end{array}$ & 1765 & 79973 & 127 & 130 & 1185 \\
$F$ & 29.4 & 46.8 & & 93386 \\
$P$ & $<0.01$ & $<0.01$ & & $18 \cdot 1$ \\
\hline
\end{tabular}

ND, not detected.

For details of dietary regimen, see p. 106.

The values are expressed as the relative density of the spots of the autoradiogram. Therefore, the absolute values are meaningless. 
be explained at present because these proteins were not observed in Western blotting experiments.

\section{DISCUSSION}

Firstly, let us consider the molecular species of IGFBP in rat plasma. At present, we agree with the discussion of Rechler et al. $(1989 a, b)$ and Yang et al. (1989) and explain our results as follows. By SDS-PAGE, four IGFBP bands are detected. The two at about $40 \mathrm{kDa}$ are IGFBP-3; these two bands are the same protein with different sugar contents. The band at $30 \mathrm{kDa}$ is IGFBP-1. The band at $22 \mathrm{kDa}$ was produced from $29 \mathrm{kDa}$ IGFBP during incubation with SDS at $60^{\circ}$, probably by the endogenous glycosidase (or, less likely, by endogenous protease). Thus, if plasma is gel-filtrated before SDS-PAGE (Fig. 2), only a little $22 \mathrm{kDa}$ protein is produced. The endogenous enzyme(s) must be contained in fractions other than those with $29 \mathrm{kDa}$ protein (probably fraction A). Furthermore, if the original plasma is treated with DSS before SDS-PAGE, $22 \mathrm{kDa}$ protein is not produced because DSS denatures the endogenous enzyme(s) or $29 \mathrm{kDa}$ IGFBP cross-linked to IGF1 is resistant to the endogenous enzyme(s). The $29 \mathrm{kDa}$ IGFBP may be the N-terminal fragment of IGFBP-3 as suggested by Rechler et al. (1989a, b) and Yang et al. (1989). We presume that $29 \mathrm{kDa}$ IGFBP exists in native plasma not bound with ALS (if $29 \mathrm{kDa}$ IGFBP is found in plasma non-covalently bound with ALS, the complex will be recovered in the fraction A of Fig. 2), because this IGFBP was found in the experiments shown in Figs. 2 and 3. These hypotheses are summarized in Fig. 4.

The present investigations extend the earlier observations and elucidate the mechanisms involved (Takahashi et al. 1990). The results show that the total amount of IGFBP and the amount of IGF-1-saturated binding proteins are affected greatly by the status of protein nutrition. As shown in the present paper, the amount of large binding protein or $150 \mathrm{kDa}$ IGFBP containing the $40 \mathrm{kDa}$ subunit, IGFBP-3, decreases greatly with protein deprivation. Although the total amount of small binding protein, which is composed of at least two components, did not change significantly, the saturability of the binding protein was affected greatly by protein deprivation. Even if $29 \mathrm{kDa}$ IGFBP is a N-terminal fragment of IGFBP-3, it is probably not an artifact produced during plasma handling, because the response of this protein to nutritional status of the animals was clearly different from that of IGFBP-3 (Tables 1 and 2).

From these results and the previous observations, we conclude the effect of protein deprivation on IGF-1 and IGFBP is as follows. When rats are deprived of dietary protein, the amount of large binding protein decreases concomitant with a decrease in IGF-1 associated with this protein. At the same time, the amount of IGF-1 bound to small binding proteins decreases because the total amount of IGF-1 in plasma decreases. The total amount of small binding protein is not affected significantly but the saturability of small binding protein decreases significantly.

There is no clear explanation at present on the physiological role of different kinds or groups of binding proteins (Cornell et al. 1987). The $150 \mathrm{kDa}$ IGFBP, which is composed of two subunits (Furlanetto, 1980; Martin \& Baxter, 1985; Baxter, 1988), has been assumed to be IGF-1 reservoir protein in humans (Busby et al. 1988a; Blum et al. 1989) because almost all IGF-1 is found associated with this protein in plasma (Moses et al. 1979). The amount of this protein is presumably regulated by the amount of acid-stable subunit (40 $\mathrm{kDa}$ ) or IGFBP-3 because relatively larger amounts of acid-labile subunit are assumed to be produced (Furlanetto, 1980; Martin \& Baxter, 1985; Baxter, 1988). However, there is no clear information concerning the tissue which produces this protein or its subunits. Fibroblasts, osteoblasts or vascular epithelial or endothelial cells have been suggested as sources (Binoux et al. 1981; Rutanen et al. 1985, 1986; Koistinen et al. 1986; Bar et al. 
1989; Schmid, et al. 1989). Very recently, IGFBP-3 mRNA was demonstrated in rat liver by Northern blot analysis (Albiston \& Herington, 1990). Before final conclusions can be drawn, detection of mRNA (or other technical approaches) of the subunits in various tissues will be required (Brewer et al. 1988; Lee et al. 1988; Brown et al. 1989).

The role of small binding proteins is not known either. Although the total amount of these proteins was not affected significantly by protein deprivation, the amount has been shown to increase during fasting (Rechler et al. 1989 b) and change diurnally (Baxter \& Cowell, 1987; Busby et al. 1988 b). It reaches maximum concentration before a meal. This diurnal rhythm will not affect the present results, because we took all the blood samples at around 11.30 hours in the morning. There is a discrepancy concerning the effect of these small binding proteins on the biological activity of IGF-1. Some experiments suggest that the binding proteins suppress the activity of IGF-1 (Knauer \& Smith, 1980; Ritvos et al. 1988) and others that they enhance the activity (Elgin et al. 1987; Busby et al. 1989). It is possible that the binding proteins enhance the IGF-1 activity in some tissues and depress it in others (DeMellow \& Baxter, 1988).

The origin of binding proteins in $22 \mathrm{kDa}$ and $15 \mathrm{kDa}$ fractions (Fig. 3) is not known yet. Baxter and his coworkers showed that the subunit of $150 \mathrm{kDa}$ binding protein, i.e. IGFBP-3, is easily dissociated to small fractions which still have a capacity to bind IGF-1 (Martin \& Baxter, 1985; Baxter, 1988). The two small binding proteins may be the product of IGFBP-3. However, further studies are required to prove this. It is also possible that one or more of these binding proteins is the IGF-1 inhibitor reported by Herington and others (Herington \& Kuffer, 1981; Ooi \& Herington, 1986, 1988; Wang et al. 1988).

The present results clearly showed that the amount of IGFBP, and possibly their saturability, is largely affected by the status of protein nutrition. IGF-1 has been suggested to play important roles in protein anabolism. If IGFBP affect the activity of IGF-1 as suggested by many investigators, elucidation of the changes in IGFBP under various nutritional conditions will be very important in the assessment of the status of protein nutrition of man, particularly in protein-deprived children or patients losing body protein because of various diseases.

\section{REFERENCES}

Albiston, A. L. \& Herington, A. C. (1990). Cloning and characterization of the growth hormone-dependent insulin-like growth factor binding protein (IGFBP-3) in the rat. Biochemical and Biophysical Research Communications 166, 892-897.

Ballard, J., Baxter, R., Binoux, M., Clemmons, D., Drop, S., Hall, K., Hintz, R., Rechler, M., Rutanen, E. \& Schwander, J. (1989). On the nomenclature of the IGF binding proteins. Acta Endocrinologica 121, 751-752.

Bar, R. S., Booth, B. A., Boes, M. \& Dake, B. L. (1989). Insulin-like growth factor-binding proteins from vascular endothelial cells: purification, characterization, and intrinsic biological activities. Endocrinology 125, $1910-1920$.

Baxter, R. C. (1988). Characterization of the acid-labile subunit of the growth hormone-dependent insulin-like growth factor binding protein complex. Journal of Clinical Endocrinology and Metabolism 67, 265-272.

Baxter, R. C. \& Cowell, C. T. (1987). Diurnal rhythm of growth hormone-independent binding protein for insulin-like growth factors in human plasma. Journal of Clinical Endocrinology and Metabolism 65, 432-440.

Baxter, R. C., Martin, J. L. \& Beniac, V. A. (1989). High molecular weight insulin-like growth factor binding protein complex. Purification and properties of the acid-labile subunit from human serum. Journal of Biological Chemistry 264, 11843-11848.

Baxter, R. C., Martin, J. L. \& Wood, M. H. (1987). Two immunoreactive binding proteins for insulin-like growth factors in human amniotic fluid: Relationship to fetal maturity. Journal of Clinical Endocrinology and Metabolism 65, 423-431.

Binoux, M., Hardouin, S., Lassarre, C. \& Hossenlopp, P. (1982). Evidence for production by the liver of two IGF binding proteins with similar molecular weights but different affinities for IGF I and IGF II. Their relations with serum and cerebrospinal fluid IGF binding proteins. Journal of Clinical Endocrinology and Metabolism 55, $600-602$.

Binoux, M., Hossenlopp, P., Lassarre, C. \& Hardouin, N. (1981). Production of insulin-like growth factors and their carrier by rat pituitary gland and brain explants in culture. FEBS Letters 124, 178-184. 
Blum, W. F., Jenne, E. W., Reppin, F., Kietzmann, K., Ranke, M. B. \& Bierich, J. R. (1989). Insulin-like growth factor I (IGF-I)-binding protein complex is a better mitogen than free IGF-I. Endocrinology 125, 766-772.

Brewer, M. T., Stetler, G. L., Squires, C. H., Thompson, R. C., Busby, W. H. \& Clemmons, D. R (1988). Cloning, characterization, and expression of a human insulin-like growth factor binding protein. Biochemical and Biophysical Research Communications 152, 1289-1297.

Brown, A. L., Chiariotti, L., Orlowski, C. C., Mehlman, T., Burgess, W. H., Ackerman, E. J., Bruni, C. B. \& Rechler, M. M. (1989). Nucleotide sequence and expression of a cDNA clone encoding a fetal rat binding protein for insulin-like growth factors. Journal of Biological Chemistry 264, 5148-5154.

Busby, W. H., Hossenlopp, P., Binoux, M. \& Clemmons, D. R. (1989). Purified preparations of the amniotic fuid-derived insulin-like growth factor-binding protein contain multimeric forms that are biologically active. Endocrinology 125, 773-777

Busby, W. H. Jr, Klapper, D. G. \& Clemmons, D. R. (1988a). Purification of a 31,000-daiton insulin-like growth factor binding protein from human amniotic fluid. Isolation of two forms with different biologic actions. Journal of Biological Chemistry 263, 14203-14210.

Busby, W. H., Snyder, D. K. \& Clemmons, D. R. (1988b). Radioimmunoassay of a 26,000-dalton plasma insulinlike growth factor-binding protein: Control by nutritional variables. Journal of Clinical Endocrinology and Metabolism 67, 1225-1230.

Cohen, K. L. \& Nissley, S. P. (1975). Comparison of somatomedin activity in rat serum and lymph. Endocrinology 97, 654-658.

Cornell, H. J., Enberg, G. \& Herington, A. C. (1987). Preferential association of the insulin-like growth factors I and II with metabolically inactive and active carrier-bound complexes in serum. Biochemical Journal 241, $745-750$.

DeMellow, J. S. M. \& Baxter, R. C. (1988). Growth hormone-dependent insulin-like growth factor (IGF) binding protein both inhibits and potentiates IGF-I-stimulated DNA synthesis in human skin fibroblasts. Biochemical and Biophysical Research Communications 156, 199-204.

Drop, S. L. S., Kortleve, D. J. \& Guyda, H. J. (1984). Isolation of a somatomedin-binding protein from preterm amniotic fluid. Development of a radioimmunoassay. Journal of Clinical Endocrinology and Metabolism 59, 899-907.

Elgin, R. G., Busby, W. H. Jr. \& Clemmons, D. R. (1987). An insulin-like growth factor (IGF) binding protein enhances the biologic response to IGF-I. Proceedings of National Academy of Sciences USA 84, 3254-3258.

Froesch, E. R., Schmidt, C., Schwander, J. \& Zapf, J. (1985). Actions of insulin-like growth factors. Annual Review of Physiology 47, 443-467.

Furlanetto, R. W. (1980). The somatomedin C binding protein: Evidence for a heterologous subunit structure. Journal of Clinical Endocrinology and Metabolism 51, 12-19.

Grant, M. B., Schmetz, I., Ressell, B., Harwood, H. J., Silverstein, J. Ir \& Merimee, T. J. (1986). Changes in insulin-like growth factors I and II and their binding protein after a single intramuscular injection of growth hormone. Journal of Clinical Endocrinology and Metabolism 63, 981-984.

Hardouin, S., Hossenlopp, P., Segovia, B., Seurin, D., Portolan, G., Lassarre, C. \& Binoux, M. (1987), Heterogeneity of insulin-like growth factor binding proteins and relationships between structure and affinity. (1) Circulating forms in man. European Journal of Biochemistry 170, 121-132.

Herington, A. C. \& Kuffer, A. D. (1981). Identification of a specific inhibitor of nonsuppressible insulin-like activity in a partially purified human serum fraction. Endocrinology 109, 1634-1640.

Hintz, R. L. \& Liu, F. (1977). Demonstration of specific plasma protein binding sites for somatomedin. Journal of Clinical Endocrinology and Metabolism 45, 988-995.

Hossenlopp, P., Seurin, D., Segovia-Quinson, B., Hardouin, S. \& Binoux, M. (1986). Analysis of serum insulinlike growth factor binding proteins using western blotting: Use of the method for titration of the binding proteins and competitive binding studies, Analytical Biochemistry 154, 138-143.

Kaufmann, U., Zapf, J. \& Froesch, E. R. (1978). Growth-hormone dependence of non-suppressible insulin-like activity (NSILA) and of NSILA-carrier protein in rats. Acta Endocrinologica 87, 716-727.

Kaufmann, U., Zapf, J., Torretti, B. \& Froesch, E. R. (1977). Demonstration of a specific serum carrier protein of non-suppressible insulin-like activity in vivo. Journal of Clinical Endocrinology and Metabolism 44, 160-166.

Knauer, D. J. \& Smith, G. L. (1980). Inhibition of biological activity of multiplication-stimulating activity by binding to its carrier protein. Proceedings of National Academy of Sciences USA 77, 7252-7256.

Koistinen, R., Kalkkinen, N., Huhtala, M. L., Seppala, M., Bohn, H. \& Rutanen, E. M. (1986). Placental protein 12 is a decidual protein that binds somatomedin and has an identical $\mathrm{N}$-terminal amino acid sequence with somatomedin-binding protein from human amniotic fluid. Endocrinology 118, 1375-1378.

Laemmli, U. K. (1970). Cleavage of structural proteins during the assembly of the head of bacteriophage T4. Nature 227, 680-685.

Lee, Y. L., Hintz, R. L., James, P. M., Lee, P. D. K., Shively, J. E. \& Powell, D. R. (1988). Insulin-like growth factor (IGF) binding protein complementary deoxyribonucleic acid from human HEP G2 hepatoma cells: Predicted protein sequence suggests an IGF binding domain different from those of the IGF-I and IGF-II receptors. Molecular Endocrinology 2, 404-411.

LeRoith, D. \& Raizada, M. K. (editors) (1989). Molecular and Cellular Biology of Insulin-like Growth Factors and Their Receptors. New York and London: Plenum Press. 
Martin, J. L. \& Baxter, R. C. (1985). Antibody against acid-stable insulin-like growth factor binding protein detects $150,000 \mathrm{~mol}$ wt growth hormone-dependent complex in human plasma. Journal of Clinical Endocrinology and Metabolism 61, 799-80I .

Martin, J. L. \& Baxter, R. C. (1986). Insulin-like growth factor-binding protein from human plasma. Purification and characterization. Journal of Biological Chemistry 261, 8754-8760.

Moses, A. C., Nissley, S. P. \& Cohen, K. L. (1976). Specific binding of a somatomedin-like polypeptide in rat serum depends on growth hormone. Nature 263, $137-140$.

Moses, A. C., Nissley, S. P., Passamani, J. \& White, R. M. (1979). Further characterization of growth hormonedependent somatomedin-binding proteins in rat serum and demonstration of somatomedin-binding proteins produced by rat liver cells in culture. Endocrinology 104, 536-546.

Ooi, G. T. \& Herrington, A. C. (1986). Covalent cross-linking of insulin-like growth factor-I to a specific inhibitor from human serum. Biochemical and Biophysical Research Communications 137, 411-417.

Ooi, G. T. \& Herrington, A. C. (1988). Recognition of insulin-like growth factor (IGF) serum binding proteins by an antibody raised against a specific IGF-inhibitor. Biochemical and Biophysical Research Communications 156, 783-791.

Povoa, G., Enberg, G., Jornvall, H. \& Hall, K. (1984). Isolation and characterization of a somatomedin-binding protein from mid-term human amniotic fluid. European Journal of Biochemistry 144, 199-204.

Rechler, M. W., Brown, A. L., Orlowski, C. C., Yang, Y. W.-H., Romanus, J. A., Chiariotti, L. \& Bruni, C. B. $(1989 a)$. Characterization and cloning of a rat insulin-like growth factor binding protein. In Molecular and Cellular Biology of Insulin-like Growth Factors and Their Receptors, pp. 395402 [D. LeRoith and M. K. Raizada, editors]. New York and London: Plenum Press.

Rechler, M. M., Yang, Y. W.-H., Brown, A. L., Orlowski, C. C. and Ooi, G. T. (1989b). Molecular characterization of insulin-like growth factor binding proteins in the rat. In Insulin-like Growth Factor Binding Proteins, pp. 133-142 [S. L. S. Drop and R. L. Hintz, editors]. Amsterdam-New York-Oxford: Excerpta Medica.

Ritvos, O., Ranta, T., Jalkanen, J., Suikkari, A. M., Voutilainen, R., Bohn, H. \& Rutanen, E. M. (1988). Insulinlike growth factor (IGF) binding protein from human decidua inhibits the binding and biological action of IGFI in cultured choriocarcinoma cells. Endocrinology 122, 2150-2157.

Rosenfeld, R. G., Pham, H., Conover, C. A., Hintz, R. L. \& Baxter, R. C. (1989). Structural and immunological comparison of insulin-like growth factor binding proteins of cerebrospinal and amniotic fluids. Journal of Clinical Endocrinology and Metabolism 68, 638-646.

Rutanen, E. M., Koistinen, R., Sjoberg, J., Julkunen, M., Wahlstrom, T., Bohn, H. \& Seppala, M. (1986). Synthesis of placental protein 12 by human endometrium. Endocrinology 118, 1067-1071.

Rutanen, E. M., Koistinen, R., Wahlstrom, T., Bohn, H., Ranta, T. \& Seppala, M. (1985). Synthesis of placental protein 12 by human decidua. Endocrinology 116, 1304-1309.

Schmid, C., Ernst, M., Zapf, J. \& Froesch, E. R. (1989). Release of insulin-like growth factor carrier proteins by osteoblasts: stimulation by estradiol and growth hormone. Biochemical and Biophysical Research Communications 160, 788-794.

Snedecor, G. W. \& Cochran, W. G. (1967). One-way classifications. Analysis of variance. In Statistical Methods, 6th ed., pp. 271-273. Ames Iowa: Iowa State University Press.

Takahashi, S., Kajikawa, M., Umezawa, T., Takahashi, S.-I., Kato, H., Miura, Y., Nam, T. J., Noguchi, T. \& Naito, H. (1990). Effect of dietary proteins on the plasma immunoreactive insulin-like growth factor$1 /$ somatomedin C concentration in the rat. British Joumal of Nutrition 63, 521-534.

Van Wyk, J. J. (1984). The somatomedins: Biological actions and physiologic control mechanisms. In Hormonal Proteins and Peptides, vol. 12, pp. 81-125.

Wang, J. F., Hampton, B., Mehlman, T., Burgess, W. H. \& Rechler, M. M. (1988). Isolation of a biologically active fragment from the carboxy terminus of the fetal rat binding protein for insulin-like growth factors. Biochemical and Biophysical Research Communications 157, 718-726.

White, R. M., Nissley, S. P., Moses, A. C., Rechler, M. M. \& Johnsonbaugh, R. E. (1981). The growth hormone dependence of a somatomedin-binding protein in human serum. Journal of Clinical Endocrinology and Metabolism 53, 49-57.

Wilkins, J. R. \& D'Ercole, A. J. (1985). Affinity-labeled plasma somatomedin-C/insulin-like growth factor I binding proteins. Journal of Clinical Investigation 75, $1350-1358$.

Yang, Y. W.-H., Wang, J.-F., Orlowski, C. C., Nissley, S. P. \& Rechler, M. M. (1989). Structure, specificity, and regulation of the insulin-like growth factor-binding proteins in adult rat serum. Endocrinology 125, 1540-1555. 